
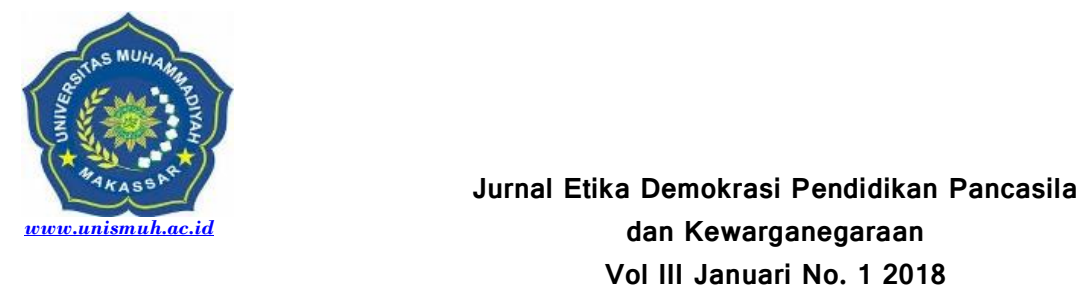

Jurnal Etika Demokrasi

\title{
Peningkatan Hasil Belajar Pendidikan Kewarganegaraan Melalui model \\ Pembelajaran Snowball Throwing Pada Murid Seolah Dasar Negeri 3 Jagon \\ Kecamatan Pangkajene Kabupaten Pangkep
}

\author{
Arahim S \\ Pendidikan Pancasila dan Kewarganegaraan FKIP Universitas Muhammadiyah Makassar \\ arahims@unismuh.ac.id
}

\begin{abstract}
The purpose of this study is to improve the learning outcomes of Citizenship Education through the model of learning Snowball Throwing on the fourth grade of elementary school students 3 District jagong district Pangkep. This research is a classroom action research conducted two cycles, each cycle. The test of the learning result can be analyzed quantitatively and the result of the observation sheet is analyzed qualitatively. The results showed that in the first cycle the average value of learning outcomes of Civics Education 65.6 students and are in the medium category with the completeness category of 11 unfinished students and 15 completed students with Minimum Exhaustiveness Criteria. In Cycle II the average value of learning outcomes Civics Education 78.27 is in the high category with the completeness category of 26 complete students. Completeness of student learning outcomes increased after the implementation at the State Elementary School 3 Jagong Pangkajene District Pangkep District that is in the first cycle there are 11 students who have not completed and in Cycle II all the students to be thorough. Based on the results of the above study, it can be concluded that the learning model of Snowball Throwing can improve the outcomes of Citizenship Education on Pupils of Class IV State Elementary School 3 Jagong Pangkajene District Pangkep District.

Keywords: Learning Outcomes, Snowball Throwing Learning Model
\end{abstract}

\begin{abstract}
Abstrak. Tujuan penelitian ini yaitu untuk meningkatkan hasil belajar Pendidikan Kewarganegaraan melalui model pembelajaran Snowball Throwing pada murid kelas IV Sekolah Dasar Negeri 3 Kecamatan jagong kabupaten Pangkep. Penelitian ini adalah Penelitian Tindakan Kelas (classroom action research) yang dilaksanakan dua siklus, setiap siklus. Tes hasil belajar dapat dianalisis secara kuantitatif dan hasil lembar observasi dianalisis secara kualitatif. Hasil penelitian menunjukkan pada siklus I nilai rata-rata hasil belajar Pendidikan Kewarganegaran murid 65,6 dan berada pada kategori sedang dengan kategori ketuntasan yaitu 11 murid yang belum tuntas dan 15 murid yang tuntas dengan Kriteria Ketuntasan Minimal. Pada Siklus II nilai rata-rata hasil belajar Pendidikan Kewarganegaran 78,27 berada pada kategori tinggi dengan kategori ketuntasan yaitu 26 murid yang tuntas. Ketuntasan hasil belajar murid meningkat setelah di terapkan di Sekolah Dasar Negeri 3 Jagong Kecamatan Pangkajene Kabupaten Pangkep yaitu pada Siklus I terdapat 11 murid yang belum tuntas dan pada Siklus II seluruh murid menjadi tuntas. Berdasarkan hasil penelitian tersebut di atas, dapat disimpulkan bahwa model pembelajaran Snowball Throwing dapat meningkatkan hasil Pendidikan Kewarganegaran pada Murid Kelas IV Sekolah Dasar Negeri 3 Jagong Kecamatan Pangkajene Kabupaten Pangkep.
\end{abstract}

Kata kunci: Hasil Belajar, Model Pembelajaran Snowball Throwing 


\section{PENDAHULUAN}

Dinamika dunia pendidikan nasional menjadi sorotan publik, khususnya bagi kalangan akademisi, pengamat, pemerintah bahkan masyarakat umum. Berbagai realita dalam dunia pendidikan mampu membawa perhatian stakeholder pendidikan untuk bersama secara kolektif memperbaiki kualitas pendidikan nasional. Beberapa komponen vital seperti, kontroversi penyelenggaraan Ujian Nasional (UN), upaya peningkatan kualitas guru (dengan berbagai macam instrumen kebijakan pemerintah), pengembangan model pembelajaran, media pembelajaran, peningkatan mutu infrastruktur pendidikan (sarana dan prasarana), akses informasi pendidikan yang mesti diperluas sampai ke pelosok daerah sampai kepada distribusi akses pendidikan yang bermuara pada pemerataan pendidikan di seluruh pelosok nusantara

Pendidikan pada hakikatnya adalah proses pendewasaan anak menuju sikap yang bertanggung jawab baik dalam pola pikir maupun tingkah laku. Dengan demikian, dalam meningkatkan mutu pendidikan tersebut maka perlu dilakukan pembenahan secara terus menerus, yakni di antaranya dengan proses pembelajaran yang efektif serta pembelajaran yang berkualitas. Pendidikan adalah suatu usaha sadar dan terencana untuk menciptakan suasana belajar agar murid secara aktif mengembangkan potensi dirinya untuk memiliki kekuatan spiritual keagamaan, pengendalian diri, kepribadian berkarakter moral, kecerdasan, sikap sosial, kreatif, inovatif, kebersamaan, masyarakat, bangsa dan Negara. Proses pendidikan yang diselenggarakan secara formal di sekolah dimulai dari pendidikan formal yang paling dasar (SD) sampai perguruan tinggi (PT) tidak lepas dari kegiatan belajar yang merupakan salah satu kegiatan pokok dengan guru sebagai pemegang peranan utama.

Proses pendidikan dalam kegiatan pembelajaran atau dala kelas, akan bisa berjalan dengan lancar, kondusif, interaktif, dan lain sebagainya apabila dilandasi oleh dasar kurikulum yang baik dan benar. Pendidikan bisa dijalankan dengan baik ketika kurikulum menjadi penyangga utama dalam proses belajar mengajar. Menurut
Nasution (Yamin, 2012: 18) "Kurikulum dianggap bermakna bila bahan pelajarn dihubungkan atau didasarkan atas pengalaman anak dalam kehidupan sehari-hari, misalnya, membicarakan masalah yang nyata seperti soal kesehatan, kecelakaan lalu-lintas, dan sebagainya".

Kurikulum Tingkat Satuan Pendidikan (KTSP) menghendaki agar guru dapat merancang dan menerapkan model pembelajaran yang memungkinkan murid merasa senang dan tidak bosan terhadap materi yang diajarkan sehingga hasil belajarnya dapat meningkat. Namun, harapan tersebut belum sesuai dengan kenyataan yang ditemuai di lapangan. Masih banyak guru yang kurang memperhatikan kesesuaian antara model pembelajaran dengan materi yang diajarkan, akibatnya hasil belajar murid rendah. Keadaan ini tidak bisa dibiarkan karena akan berpengaruh dengan hasil belajar murid. Oleh karena itu, pembelajaran tersebut perlu diperbaiki agar tujuan KTSP dapat tercapai. Komponen-komponen pendidikan dasar merupakan satu kesatuan yang turut mententukan keberhasilan Pendidikan Sekolah Dasar, salah satu komponen yang dimaksud adalah bidang pengajaran diantaranya Pendidikan Kewarganegaraan.

Tugas guru sebagai fasilitator dan pembimbing adalah memberikan bantuan dan arahan. Ketika murid menemukan permasalahan dalam menyelesaikan tugas, selain berinteraksi dengan guru murid juga dapat bertanya dan berdiskusi dengan murid lain. Murid dikatakan belajar dengan aktif jika mereka mendominasi aktifitas pembelajaran. Murid secara aktif menggunakan otak, baik untuk menemukan ide pokok dari materi, memecahkan persoalan, atau mengaplikasikan apa yang di pelajari. Aktivitas dalam suatu pembelajaran, bukan hanya murid yang aktif belajar, tapi di lain pihak, guru harus mengorganisasikan suatu kondisi yang dapat mengaktifkan murid dalam belajar. Oleh karena itu, salah satu usaha yang dapat dilakukan guru adalah merencanakan dan menggunakan model pembelajaran yang dapat mengkondisikan murid agar belajar secara aktif. Lie (2002: 8) menyatakan bahwa "Rendahnya hasil belajar anak didik, salah 
satu penyebabnya adalah lemahnya strategi pembelajaran yang diterapkan oleh guru sebagai pengajar. Kelemahan itu ditandai oleh kurangnya media yang menyertai proses belajar mengajar, sehingga berdampak pada pengelolaan kelas yang belum optimal. Anak didik dalam kegiatan belajar mengajar masih ditemukan berbagai kelemahan antara lain: kurangnya keaktifan dalam pembelajaran, kurangnya kemandirian dalam mengemukakan pendapat, kurang bekerjasama, kurangnya menghargai pendapat orang lain, kurang mengontrol diri, kurang sportif, dan kurangnya memotivasi teman belajar sehingga iklim kelas yang terciptapun menjadi kurang kondusif".

Guru dan murid merupakan komponen utama dalam proses pembelajaran. Guru diharapkan dapat membimbing murid sedemikian rupa, sehingga mereka dapat mengembangkan pengetahuannya sesuai dengan struktur pengetahuan bidang studi yang dipelajari, disamping harus memahami sepenuhnya materi yang diajarkan, guru juga dituntut untuk mengetahui secara tepat dimana tingkat pengetahuan murid pada awal atau sebelum mengikuti pelajaran tertentu. Menurut Winataputra (2012: 1) bahwa "Secara akademis Pendidikan Kewarganegaraan didefinisikan sebagai suatu bidang kajian yang memusatkan telaahnya pada seluruh dimensi psikologis dan sosial budaya kewarganegaraan individu, dengan menggunakan ilmu politik, ilmu pendidikan sebagai landasan kajiannya atau penemuannya. Intinya yang diperkaya disiplin ilmu-ilmu lain yang relevan, dan mempunyai implikasi kebermanfaatan terhadap instrumentasi dan praksis pendidikan setiap warga negara dalam konteks sistem pendidikan nasional". Mata pelajaran Pendidikan Kewarganegaraan merupakan salah satu instrumen fundamental dalam bingkai pendidikan nasional sebagai media bagi pembentukan karakter bangsa (Nation and Character Building) di tengah pluralisme yang menjadi karakteristik utama bangsa Indonesia. Bangsa Indonesia memiliki ragam perbedaan dan menjadi kekayaan manusia Indonesia. Perbedaan suku, budaya, adat-istiadat, agama, ras, gender, strata sosial dan golongan/aliansi politik sangat jelas melekat dalam diri masyarakat Indonesia. Pluralitas menjadi sebuah realita dan mesti diterima sebagai kekayaan nasional bangsa Indonesia. Di tengah banyak perbedaan tersebut, sebagai suatu kesatuan nasional bangsa Indonesia harus hidup dan bergaul agar integritas nasional tetap terjaga.

Berdasarkan informasi dan hasil observasi di Sekolah Dasar Negeri 3 Jagong Kecamatan Pangkajene Kabupaten Pangkep pada saat proses pembelajaran Pendidikan Kewarganegaraan di Sekolah Dasar Negeri 3 Jagong Kecamatan Pangkajene Kabupaten Pangkep selama ini lebih ditekankan kepada penguasaan bahan/materi pelajaran sebanyak mungkin, sehingga suasana belajar bersifat kaku, dan terpusat pada satu arah serta tidak memberikan kesempatan bagi murid untuk belajar lebih aktif. Selain itu data tentang hasil belajar menunjukkan bahwa rata-rata hasil ujian semester untuk mata pelajaran Pendidikan Kewarganegaraan mendapatkan nilai rata-rata 62.45 dimana murid yang tuntas hanya mencapai 8 murid sedangkan yang tidak tuntas dan 18 orang murid yang hanya mencapai ketuntasan dari 26 orang murid sementara Kriteria Ketuntasan Minimal (KKM) untuk mata pelajaran Pendidikan Kewarganegaraan yaitu 65. Hal tersebut merupakan sebuah permasalahan yang harus dicari jawabannya.

Salah satu faktor keberhasilan dalam proses pembelajaran adalah pendekatan mengajar, saat ini masih banyak guru yang menganut paradigma lama yaitu guru masih menganggap dalam proses pembelajaran hanya ada transfer pengetahuan dari guru kepada murid. Sudah seharusnya kegiatan belajar mengajar juga lebih mempertimbangkan murid. Alur proses belajar tidak harus berasal dari guru menuju murid, murid bisa juga saling mengajar dengan sesama murid lainnya.

\section{METODE PENELITIAN}

Penelitian ini tergolong penelitian tindakan yang berbasis kelas (classroom action research) hal ini sesuai dengan Burns (1999) dalam Sanjaya (2010:23) yang menyatakan bahwa "PTK adalah penerapan berbagai fakta yang ditemukan untuk 
memecahkan masalah dalam situasi sosial untuk meningkatkan kualitas tindakan yang dilakukan dengan melibatkan kolaborasi dan kerjasama para peneliti dengan praktisi". Bertujuan untuk meningkatkan hasil belajar Pendidikan Kewarganegaraan murid kelas IV Sekolah Dasar Negeri 3 Jagong Kecamatan Pangkajene Kabupaten Pangkep melalui penerapan Model pembelajaran Snowball Throwing". Penelitian ini dilaksanakan di Sekolah Dasar Negeri 3 Jagong Kecamatan Pangkajene Kabupaten Pangkep. Subyek penelitian ini adalah seluruh murid kelas IV Sekolah Dasar Negeri 3 Jagong Kecamatan Pangkajene Kabupaten Pangkep yang bejumlah 26 orang.

Penelitian berlangsung selama dua bulan dan dilaksanakan dalam dua siklus yang terdiri dari beberapa tahap yaitu: 1) tahap perencanaan tindakan, 2) pelaksanaan tindakan, 3) observasi dan refleksi. Instrumen dalam penelitian ini dilakukan dengan tes, observasi, dan dokumentasi.

Adapun teknik pengumpulan data yang dilakukan dalam penelitian ini adalah (a) Data tentang hasil belajar Pendidikan Kewarganegaraan yang diperoleh dengan menggunakan tes hasil belajar pada setiap akhir tahap. (b) Untuk data mengenai kaaktifan dan kesungguhan murid dalam mengikuti proses belajar akan diambil pada saat proses pembelajaran berlangsung dengan menggunakan pedoman observasi.

Data yang diperoleh dari pelaksanaan observasi dianalisa secara kualitatif sedangkan data hasil belajar Pendidikan Kewarganegaraan murid kelas IV dianalisa secara kuantitatif dengan menggunakan statistik deskriptif yaitu skor ratarata, Sekolah Dasar Negeri 3 Jagong Kecamatan Pangkajene Kabupaten Pangkep persentase, standar deviasi, nilai minimun dan nilai maksimun yang dicapai murid setiap siklus.

Perhitungan persentase kemampuan tiap responden dengan menggunakan rumus sebagai berikut :

$$
\mathrm{P}=\frac{\mathrm{F}}{\mathrm{N}} \times 100 \%
$$

Ket :

$$
\mathrm{P}=\text { Kemampuan }
$$

$$
\begin{aligned}
& F=\text { Jumlah jawaban benar } \\
& N=\text { Jumlah item } \\
& \text { Sumber : Tiro (2002:73) }
\end{aligned}
$$

Kriteria yang digunakan untuk menentukan kategori hasil belajar murid adalah berdasarkan teknik kategorisasi skala lima. Menurut Depdikbud (2006: 7) bahwa: skor standar umum yang digunakan adalah skala lima yaitu pembagian tingkat penguasaan yang terbagi atas lima kategori, yaitu :

Tabel 3.1 Kategori Hasil Belajar dengan Skala Lima

\begin{tabular}{cc}
\hline Nilai & Kategori \\
\hline $\mathbf{9 0 - 1 0 0}$ & Sangat Tinggi \\
\hline $\mathbf{8 0 - 8 9}$ & Tinggi \\
\hline $\mathbf{7 0 - 7 9}$ & Sedang \\
\hline $60-69$ & Rendah \\
\hline $0-59$ & Sangat Rendah
\end{tabular}

Sumber : Depdikbud (2006: 7)

Indikator dari penilaian ini adalah apabila dilaksanakan akan terjadi peningkatan skor ratarata hasil belajar Pendidikan Kewarganegaraan dari tahap pertama ke tahap kedua. Perlakuan dianggap berhasil apabila mengcapai nilai ketuntasan individu mencapai 65 dan ketuntasan secara klasikal harus mencapai $85 \%$ dari jumlah murid secara keseluruhan

\section{PEMBAHASAN}

\section{Penelitian Tindakan Siklus I \\ Perencanaan Tindakan}

Materi pembelajaran yang dilaksanakan pada siklus I adalah pengaruh globalisasi pokok bahasan tersebut diambil dari KTSP kelas IV Sekolah Dasar Negeri 3 Jagong Kecamatan Pangkajene Kabupaten Pangkep. Perencanaan tersebut disusun dan dikembangkan oleh Peneliti serta dikonsultasikan dengan guru kelas IV Sekolah Dasar Negeri 3 Jagong Kecamatan Pangkajene Kabupaten Pangkep. Perencanaan siklus I dilaksanakan dalam 2 kali pertemuan dengan alokasi waktu satu kali pertemuan adalah $4 \times 35$ menit. Mencapai TPK, perencanaan pembelajaran dibagi dalam 3 kegiatan 
yaitu (1) kegiatan awal (2) kegiatan inti (3) kegiatan akhir. Meskipun perencanaan ini dibagi menjadi tiga kegiatan, namun setiap kegiatan tidak berdiri sendiri, tetapi saling berkaitan antara satu kegiatan dengan kegiatan lainnya. Berdasarkan materi yang akan dibahas pada siklus I peneliti kemudian membuat Rencana Pelaksanaan Pembelajaran (RPP), Lembar observasi guru dan murid, soal instrumen siklus I

\section{Pelaksanaan Tindakan}

Pembelajaran untuk siklus I berlangsung selama 70 menit ( $2 \times$ pertemuan) dan tes dilakukan pada akhir siklus I selama 35 menit $(1 \mathrm{x}$ pertemuan). Dalam pelaksanaan siklus, peneliti bertindak sebagai observer. Pada kegiatan awal guru mengajak murid membaca do'a sebelum belajar, mengabsen murid, memberi motivasi belajar dengan melakukan Tanya jawab dengan murid mengenai pengaruh globalisasi.

Pembelajaran memasuki tahap kegiatan inti selanjutnya yang merupakan kegiatan terpenting yaitu model pembelajaran Snowball Throwing. Guru menjelaskan materi pelajaran tentang pengaruh globalisasi, guru membentuk kelompokkelompok dan memanggil masing-masing ketua kelompok untuk memberikan penjelasan tentang materi, guru mengarahkan kepada masing-masing ketua kelompok kembali ke kelompoknya masingmasing, kemudian menjelaskan materi yang disiapkan oleh guru kepada temannya, kemudian masing-masing murid diberikan satu lembar kertas kerja, untuk menuliskan satu pertanyaan (apa saja) yang menyangkut materi yang sudah dijelaskan oleh ketua kelompok, kertas yang berisi pertanyaan tersebut kemudian dibuat seperti bola dan dilempar dari satu murid kemurid lain selama \pm 15 menit, setelah waktu melempar habis, setiap murid akan mendapatkan satu bola kertas yang berisi pertanyaan. Murid tersebut kemudian diberikan kesempatan untuk menjawab pertanyaan yang tertulis dalam kertas tersebut secara bergantian kupon diberi hadiah, guru bersama murid mengidentifikasi pertanyaan-pertanyaan yang ada pada bola tersebut.

Pada kegiatan akhir, guru menyimpulkan materi, guru bertanya jawab untuk mengetahui penguasaan materi yang telah dipelajari dan didiskusikan, menutup pelajaran dengan membaca do'a

\section{Observasi}

Kegiatan observasi dalam pelaksanaan tindakan siklus I diamati oleh satu orang pengamat yaitu peneliti dan guru kelas IV Sekolah Dasar Negeri 3 Jagong Kabupaten Pangkep yang melaksanakan tindakan.

\section{Hasil Observasi Guru}

Melaporkan bahwa guru dalam pembelajaran tindakan siklus I dalam pelaksanaan pembelajaran masih ada beberapa indikator penilaian yang belum dilaksanakan (a) Mengajak tidak mengajak murid membaca do'a sebelum belajar, (b) Guru tidak memberi motivasi belajar dengan melakukan Tanya jawab dengan murid mengenai pengaruh globalisasi, (c) Guru tidak mengarahkan kepada masing-masing ketua kelompok kembali ke kelompoknya masing-masing, kemudian menjelaskan materi yang disiapkan oleh guru kepada temannya, (d) Guru tidak mengarahkan masing-masing murid diberikan satu lembar kertas kerja, untuk menuliskan satu pertanyaan (apa saja) yang menyangkut materi yang sudah dijelaskan oleh ketua kelompok, (e) Guru tidak bersama murid mengidentifikasi pertanyaan-pertanyaan yang ada pada bola tersebut, (f) Guru tidak menyimpulkan materi, (g) Guru tidak menutup pelajaran dengan memberi pesan-pesan moral

Indikator yang terlaksana dalam pembelajaran tindakan siklus I pertemuan I dalam pelaksanaan pembelajaran yang dilaksanakan yaitu (a) Mengabsen murid, (b) Guru menjelaskan materi pelajaran tentang pengaruh globalisasi, (c) Guru membentuk kelompok-kelompok dan memanggil masing-masing ketua kelompok untuk memberikan penjelasan tentang materi, (d) Kertas yang berisi pertanyaan tersebut kemudian dibuat seperti bola dan dilempar dari satu murid kemurid lain selama \pm 15 menit, (e) Setelah waktu melempar habis, setiap murid akan mendapatkan satu bola kertas yang berisi pertanyaan. Murid tersebut kemudian diberikan kesempatan untuk menjawab pertanyaan 
yang tertulis dalam kertas tersebut secara bergantiankupon diberi hadiah (f) Guru bertanya jawab untuk mengetahui penguasaan materi yang telah dipelajari dan didiskusikan

\section{Hasil Observasi Murid}

Pada siklus I pertemuan I dan pertemuan II murid yang melakukan kerja sama pada saat proses pembelajaran berlangsung siklus I pertemuan I hanya $46.15 \%$ atau 12 orang murid dan mengalami peningkatan pada pertemuan II hanya $61.54 \%$ atau 16 orang murid dari jumlah murid yang hadir yaitu 26 orang, murid yang aktif dalam kelompok pada saat proses pembelajaran berlangsung siklus I pertemuan I yaitu hanya $53.85 \%$ atau 14 sedangkan pada pertemuan II mengalami peningkatan yaitu hanya $65.38 \%$ atau 17 orang murid dari jumlah murid yang hadir yaitu 26 orang, murid yang dapat membuat pertanyaan pada siklus I pertemuan I hanya $50 \%$ atau 13 orang murid kemudian mengalami peningkatan pada pertemuan II hanya 61.54\% atau 16 orang murid dari jumlah murid yang hadir yaitu 26 orang, murid yang dapat menjawab pertanyaan dengan benar dalam mengikuti proses pembelajaran yang berlangsung pada siklus I pertemuan I yaitu hanya $53.85 \%$ atau 14 orang murid kemudian meningkat pada pertemuan II yaitu $65.38 \%$ atau 17 orang murid dari jumlah murid yang hadir yaitu 26 orang murid.

\section{Hasil Belajar Siklus I}

Pada akhir siklus I ini, diperoleh gambaran tentang hasil belajar Pendidikan Kewarganegaraan di kelas IV yang menjadi subjek penelitian dengan pokok bahasan pengaruh globalisasi. Tes akhir siklus ini diikuti oleh semua murid kelas IV Sekolah Dasar Negeri 3 Jagong Kecamatan Pangkajene Kabupaten Pangkep yang berjumlah 26 orang.

Tabel 4.4. Statistik Hasil Tes Murid pada Siklus I

\begin{tabular}{cc}
\hline Statistik & Nilai Statistik \\
\hline Subjek & 26 \\
Nilai ideal & 100 \\
Nilai tertinggi & 90 \\
Nilai terendah & 50 \\
Rentang Nilai & 40 \\
Nilai rata-rata & 65.6 \\
\hline
\end{tabular}

Sumber: Analisis data hasil tes murid
Tabel 4.4 diatas diperoleh informasi bahwa nilai rata-rata hasil belajar murid IV Sekolah Dasar Negeri 3 Jagong Kecamatan Pangkajene Kabupaten Pangkep setelah proses belajar mengajar dengan menerapka model pembelajaran Snowball Throwing yang dilaksanakan pada Siklus I adalah 65.6 dengan nilai ideal yang mungkin dicapai 100 . Sedangkan secara individual, nilai yang dicapai responden tersebar dari nilai terendah 50 dari nilai minimum ideal yang mungkin dicapai 0 sampai dengan nilai tertinggi 90 dari nilai ideal yang mungkin dicapai 100 dengan rentang nilai 40. Jika nilai penguasaan murid di atas dikelompokkan ke dalam lima kategori maka diperoleh distribusi frekuensi nilai seperti ditunjukkan pada Tabel 4.5 berikut ini.

Tabel 4.5 Distribusi Frekuensi dan Persentase Nilai Hasil Belajar Murid kelas IV Sekolah Dasar Negeri 3 Jagong Kecamatan Pangkajene Kabupaten Pangkep pada Siklus I

\begin{tabular}{|c|c|c|c|c|}
\hline No & Nilai & Kategori & Frek & (\%) \\
\hline 1. & $90-100$ & Sangat Tinggi & 1 & 3.85 \\
\hline 2. & $80-89$ & Tinggi & 5 & 19.23 \\
\hline 3. & $70-79$ & Sedang & 8 & 30.77 \\
\hline 4. & $60-69$ & Rendah & 5 & 19.23 \\
\hline \multirow[t]{2}{*}{5.} & $0-59$ & Sangat Rendah & 7 & 26.92 \\
\hline & & imlah & 26 & 100.00 \\
\hline
\end{tabular}

Sumber: Analisis data hasil tes murid

Berdasarkan tabel 4.5 di atas dapat dikemukakan bahwa dari 26 murid kelas IV Sekolah Dasar Negeri 3 Jagong Kecamatan Pangkajene Kabupaten Pangkep 3.85\% murid yang masuk dalam kategori sangat tinggi, $19.23 \%$ masuk dalam kategori tinggi, $30.77 \%$ masuk dalam kategori sedang, $19.23 \%$ masuk dalam kategori rendah dan 26.92\% masuk dalam kategori sangat rendah.

Nilai rata-rata hasil belajar murid yang diperoleh setelah proses belajar mengajar selama Siklus I berlangsung yaitu sebesar 65.6. Setelah dikategorisasikan berdasarkan tabel di atas, mengetahui bahwa tingkat hasil belajar murid kelas IV Sekolah Dasar Negeri 3 Jagong Kecamatan Pangkajene Kabupaten Pangkep berada ada kategori sedang. Apabila tes hasil belajar murid pada Siklus I kemudian dikategorikan dalam kriteria ketuntasan minimum yang berlaku di Sekolah Dasar Negeri 3 Jagong Kecamatan Pangkajene Kabupaten 
Pangkep untuk mata pelajaran Pendidikan Kewarganegaraan pokok pengaruh globalisasi maka diperoleh persentase ketuntasan belajar murid pada Siklus I seperti pada Tabel 4.6 berikut.

Tabel 4.6 Deskripsi Ketuntasan hasil Belajar murid kelas IV Sekolah Dasar Negeri 3 Jagong Kecamatan Pangkajene Kabupaten Pangkep pada Siklus I

\begin{tabular}{cccc}
\hline $\begin{array}{c}\text { kriteria } \\
\text { Ketuntasan }\end{array}$ & Kategori & Frekuensi & $\begin{array}{c}\text { Persen } \\
(\%)\end{array}$ \\
\hline $\begin{array}{c}0-64 \\
65-100\end{array}$ & Tidak & 11 & $\mathbf{4 2 . 3 1}$ \\
& tuntas & 15 & $\mathbf{5 7 . 6 9}$ \\
& Tuntas & & \\
\hline Jumlah & 26 & 100
\end{tabular}

Sumber: Analisis data hasil tes murid

Tabel 4.6 dapat dilihat bahwa persentase ketuntasan belajar murid setelah diterapkannnya model pembelajaran Snowball Throwing sebesar $57.69 \%$ atau 11 orang murid dari 26 orang murid termasuk dalam kategori tuntas, dan $42.31 \%$ atau 11 orang murid dari 26 orang murid termasuk dalam kategori tidak tuntas.

Hal tersebut menunjukkan bahwa masih terdapat 11 murid perlu perbaikan karena belum mencapai kriteria ketuntasan minimum yang ditetapkan yaitu 65.00 .

\section{Refleksi}

Pelaksanaan tindakan kegiatan siklus । difokuskan model pembelajaran Snowball Throwing dengan pokok bahasan pengaruh globalisasi. Untuk memperoleh data tentang pelaksanaan tindakan siklus I dilakukan pengamatan, tes, dan dokumentasi. Hasil pengamatan, tes, dan dokumentasi selama pelaksanaan tindakan dianalisis dan didiskusikan dengan pengamat sehingga diperoleh hal-hal sebagai berikut:

a. Pada kegiatan awal tidak meberikan motivasi dengan melakukan Tanya jawab dengan murid mengenai pengaruh globalisasi

b. Pada kegiatan inti guru mengarahkan kepada masing-masing ketua kelompok kembali ke kelompoknya masing-masing, kemudian menjelaskan materi yang disiapkan oleh guru kepada temannya, Guru bersama murid mengidentifikasi pertanyaan-pertanyaan yang ada pada bola tersebut c. Pada kegiatan akhir guru tidak menyimpulkan materi pelajaran.

Setelah mengamati dan mengerjakan soal yang telah diberikan masih ditemukan murid yang belum sepenuhnya mengerti materi yang diajarkan sehingga murid dalam mengerjakan soal tes ditemukan juga beberapa murid yang belum memahami materi tersebut.

\section{Penelitian Tindakan Siklus II Perencanaan Tindakan}

Materi pembelajaran yang dilaksanakan pada siklus II adalah pengaruh globalisasi pokok bahasan tersebut diambil dari KTSP kelas IV Sekolah Dasar Negeri 3 Jagong Kecamatan Pangkajene Kabupaten Pangkep. Perencanaan tersebut disusun dan dikembangkan oleh Peneliti serta dikonsultasikan dengan guru kelas IV Sekolah Dasar Negeri 3 Jagong Kecamatan Pangkajene Kabupaten Pangkep. Perencanaan siklus II dilaksanakan dalam 2 kali pertemuan dengan alokasi waktu satu kali pertemuan adalah $4 \times 35$ menit.

Mencapai TPK, perencanaan pembelajaran dibagi dalam 3 kegiatan yaitu (1) kegiatan awal (2) kegiatan inti (3) kegiatan akhir. Meskipun perencanaan ini dibagi menjadi tiga kegiatan, namun setiap kegiatan tidak berdiri sendiri, tetapi saling berkaitan antara satu kegiatan dengan kegiatan lainnya. Berdasarkan materi yang akan dibahas pada siklus II peneliti kemudian membuat Rencana Pelaksanaan Pembelajaran (RPP), Lembar observasi guru dan murid, soal instrumen siklus II.

\section{Pelaksanaan Tindakan}

Pembelajaran untuk siklus II berlangsung selama 70 menit. Dalam pelaksanaan siklus, peneliti bertindak sebagai observer. Pada kegiatan awal guru mengajak murid membaca do'a sebelum belajar, mengabsen murid, memberi motivasi belajar dengan melakukan Tanya jawab dengan murid mengenai pengaruh globalisasi.

Pembelajaran memasuki tahap kegiatan inti selanjutnya yang merupakan kegiatan terpenting yaitu model pembelajaran Snowball Throwing. Guru menjelaskan materi pelajaran tentang pengaruh globalisasi, guru membentuk kelompok- 
kelompok dan memanggil masing-masing ketua kelompok untuk memberikan penjelasan tentang materi, guru mengarahkan kepada masing-masing ketua kelompok kembali ke kelompoknya masingmasing, kemudian menjelaskan materi yang disiapkan oleh guru kepada temannya, kemudian masing-masing murid diberikan satu lembar kertas kerja, untuk menuliskan satu pertanyaan (apa saja) yang menyangkut materi yang sudah dijelaskan oleh ketua kelompok, kertas yang berisi pertanyaan tersebut kemudian dibuat seperti bola dan dilempar dari satu murid kemurid lain selama \pm 15 menit, setelah waktu melempar habis, setiap murid akan mendapatkan satu bola kertas yang berisi pertanyaan. Murid tersebut kemudian diberikan kesempatan untuk menjawab pertanyaan yang tertulis dalam kertas tersebut secara bergantiankupon diberi hadiah, guru bersama murid mengidentifikasi pertanyaan-pertanyaan yang ada pada bola tersebut.

Pada kegiatan akhir, guru menyimpulkan materi, guru bertanya jawab untuk mengetahui penguasaan materi yang telah dipelajari dan didiskusikan, menutup pelajaran dengan membaca do'a

\section{Observasi}

Kegiatan observasi dalam pelaksanaan tindakan siklus II diamati oleh satu orang pengamat yaitu peneliti dan guru kelas IV Sekolah Dasar Negeri 3 Jagong Kecamatan Pangkajene Kabupaten Pangkep yang melaksanakan tindakan.

\section{Hasil Observasi Guru}

Melaporkan bahwa guru dalam pembelajaran tindakan siklus II pertemuan I dan pertemuan II dalam pelaksanaan pembelajaran semua indikator penilaian terlaksanakan dengan baik yaitu (a) Mengajak murid membaca do'a sebelum belajar, (b) Mengabsen murid, (c) Memberi motivasi belajar dengan melakukan Tanya jawab dengan murid mengenai pengaruh globalisasi, (d) Guru menjelaskan materi pelajaran tentang pengaruh globalisasi, (e) Guru membentuk kelompok-kelompok dan memanggil masingmasing ketua kelompok untuk memberikan penjelasan tentang materi, (f) Guru mengarahkan kepada masing-masing ketua kelompok kembali ke kelompoknya masing-masing, kemudian menjelaskan materi yang disiapkan oleh guru kepada temannya, (g) Kemudian masing-masing murid diberikan satu lembar kertas kerja, untuk menuliskan satu pertanyaan (apa saja) yang menyangkut materi yang sudah dijelaskan oleh ketua kelompok, (h) Kertas yang berisi pertanyaan tersebut kemudian dibuat seperti bola dan dilempar dari satu murid kemurid lain selama \pm 15 menit, (i) Setelah waktu melempar habis, setiap murid akan mendapatkan satu bola kertas yang berisi pertanyaan. Murid tersebut kemudian diberikan kesempatan untuk menjawab pertanyaan yang tertulis dalam kertas tersebut secara bergantiankupon diberi hadiah, (j) Guru bersama murid mengidentifikasi pertanyaan-pertanyaan yang ada pada bola tersebut, (k) Guru menyimpulkan materi, (I) Guru bertanya jawab untuk mengetahui penguasaan materi yang telah dipelajari dan didiskusikan, (m) Menutup pelajaran dengan memberi pesan-pesan moral.

\section{Hasil Observasi Murid}

Pada siklus II pertemuan I dan pertemuan II murid yang melakukan kerja sama pada saat proses pembelajaran berlangsung siklus II pertemuan I yaitu $84.62 \%$ atau 22 orang murid dan mengalami peningkatan pada pertemuan II sebanyak $96.15 \%$ atau 25 orang murid dari jumlah murid yang hadir yaitu 26 orang, murid yang aktif dalam kelompok pada saat proses pembelajaran berlangsung siklus II pertemuan I yaitu $80.77 \%$ atau 21 sedangkan pada pertemuan II mengalami peningkatan sebanyak $100 \%$ atau 26 orang murid dari jumlah murid yang hadir yaitu 26 orang, murid yang dapat membuat pertanyaan pada siklus II pertemuan I yaitu $80.77 \%$ atau 21 orang murid kemudian mengalami peningkatan pada pertemuan II sebanyak $96.15 \%$ atau 25 orang murid dari jumlah murid yang hadir yaitu 26 orang, murid yang dapat menjawab pertanyaan dengan benar dalam mengikuti proses pembelajaran yang berlangsung pada siklus I pertemuan I yaitu $84.62 \%$ atau 22 orang murid kemudian meningkat pada pertemuan II yaitu 
sebanyak $100 \%$ atau 26 orang murid dari jumlah murid yang hadir yaitu 26 orang murid.

\section{Hasil Belajar}

Siklus II merupakan lanjutan dari siklus I yang telah mengalami refleksi, sehingga dari hasil tes pada siklus I kita bisa melihat bagaimana perkembangan hasil belajar murid kelas IV terhadap mata pelajaran Pendidikan Kewarganegaraan pokok bahasan pengaruh globalisasi setelah tindakan kelas yaitu model pembelajaran Snowball Throwing. Tes akhir siklus II ini diikuti oleh semua murid kelas IV yang berjumlah 26 orang. Adapun data nilai hasil tes murid pada akhir siklus II dapat dilihat pada tabel 4.8 berikut ini.

Tabel 4.8. Statistik Hasil Tes Murid pada Siklus II

\begin{tabular}{cc}
\hline Statistik & Nilai Statistik \\
\hline Subjek & 26 \\
Nilai ideal & 100 \\
Nilai tertinggi & 95 \\
Nilai terendah & 65 \\
Rentang Nilai & 30 \\
Nilai rata-rata & 78.27 \\
\hline
\end{tabular}

Sumber: Analisis data hasil tes murid

Tabel 4.8 diperoleh informasi bahwa nilai rata-rata hasil belajar murid kelas IV Sekolah Dasar Negeri 3 Jagong Kecamatan Pangkajene Kabupaten Pangkep setelah proses belajar mengajar melalui model pembelajaran Snowball Throwing yang dilaksanakan pada Siklus II adalah 78.27 dengan nilai ideal yang mungkin dicapai 100 . Sedangkan secara individual, nilai yang dicapai responden tersebar dari nilai terendah 65 dari nilai minimum ideal yang mungkin dicapai 0 sampai dengan nilai tertinggi 95 dari nilai ideal yang mungkin dicapai 100 dengan rentang nilai 30 . Jika nilai penguasaan murid di atas dikelompokkan ke dalam lima kategori maka diperoleh distribusi frekuensi nilai seperti ditunjukkan pada Tabel 4.9 berikut ini.

Tabel 4.9 Distribusi Frekuensi dan Persentase Skor Hasil Belajar Murid kelas IV Sekolah Dasar Negeri 3 Jagong Kecamatan Pangkajene Kabupaten Pangkep pada Siklus II

\begin{tabular}{ccccc}
\hline No & Nilai & Kategori & Frekuensi & $(\%)$ \\
\hline 1. & $90-100$ & Sangat Tinggi & 4 & $\mathbf{1 5 . 3 8}$ \\
\hline
\end{tabular}

$\begin{array}{lcccc}\text { 2. } & 80-89 & \text { Tinggi } & 10 & \mathbf{3 8 . 4 6} \\ \text { 3. } & 70-79 & \text { Sedang } & 9 & \mathbf{3 4 . 6 2} \\ \text { 4. } & 60-69 & \text { Rendah } & 3 & \mathbf{1 1 . 5 4} \\ \text { 5. } & 0-59 & \text { Sangat } & 0 & \mathbf{0 . 0 0} \\ & \text { Rendah } & & 100.00\end{array}$

Sumber: Analisis data hasil tes murid

Berdasarkan tabel 4.9 di atas dapat dikemukakan bahwa dari 26 murid kelas IV Sekolah Dasar Negeri 3 Jagong Kecamatan Pangkajene Kabupaten Pangkep $16.67 \%$ murid yang masuk dalam kategori sangat tinggi, 36.67\% masuk kategori tinggi, 33.33\% masuk dalam kategori sedang, $13.33 \%$ masuk dalam kategori rendah dan tidak ada masuk dalam kategori sangat rendah.

Nilai rata-rata hasil belajar murid yang diperoleh setelah proses belajar mengajar selama Siklus II berlangsung yaitu sebesar 78.33 Setelah dikategorisasikan berdasarkan tabel di atas, mengetahui bahwa hasil belajar murid kelas IV Sekolah Dasar Negeri 3 Jagong Kecamatan Pangkajene Kabupaten Pangkep berada ada kategori Tinggi.

Apabila tes hasil belajar murid pada Siklus II kemudian dikategorikan dalam kriteria ketuntasan minimum yang berlaku di Sekolah Dasar Negeri 3 Jagong Kecamatan Pangkajene Kabupaten Pangkep untuk mata Pendidikan Kewarganegaraan pokok bahasan pengaruh globalisasi maka diperoleh persentase ketuntasan belajar murid pada Siklus II seperti pada Tabel 4.10

Tabel 4.10 Deskripsi Ketuntasan Belajar Murid kelas IV Sekolah Dasar Negeri 3 Jagong Kecamatan Pangkajene Kabupaten Pangkep pada Siklus II

\begin{tabular}{cccc}
\hline $\begin{array}{c}\text { Kriteria } \\
\text { Ketuntasan }\end{array}$ & Kategori & Frekuensi & $\begin{array}{c}\text { Persen } \\
(\%)\end{array}$ \\
\hline $\mathbf{0 - 6 4}$ & Tidak tuntas & 0 & $\mathbf{0 . 0 0}$ \\
$\mathbf{6 5 - 1 0 0}$ & Tuntas & 26 & $\mathbf{1 0 0}$ \\
\hline \multicolumn{2}{c}{ Jumlah } & 26 & 100
\end{tabular}

Sumber: Analisis data hasil tes murid

Tabel 4.10 dapat di lihat bahwa persentase ketuntasan belajar murid setelah diajar melalui penerapan model pembelajaran Snowball Throwing sebesar 26 murid termasuk dalam kategori tuntas dan tidak ada murid yang masuk dalam kategori tidak tuntas. Hal tersebut menunjukkan bahwa jumlah murid yang berada dalam kategori tuntas 
mengalami peningkatan yakni 15 orang atau 57.69\% pada Siklus I, kemudian naik menjadi 26 orang atau $100 \%$ pada Siklus II. Hal ini juga menunjukkan bahwa ketuntasan hasil belajar murid diatas $85 \%$. Untuk melihat peningkatan hasil belajar PKn melalui penerapan model pembelajaran Snowball Throwing berdasarkan hasil tes untuk setiap siklus akan disajikan secara sederhana pada tabel 4.11 berikut:

Tabel 4.11 Gambaran Peningkatan Hasil Belajar Murid kelas IV Sekolah Dasar Negeri 3 Jagong Kecamatan Pangkajene Kabupaten Pangkep pada setiap siklus

\begin{tabular}{ccc|cccc}
\hline Hasil & \multicolumn{3}{|c|}{ Ketuntasan } & \multicolumn{4}{c}{ Skor } & $\%$ \\
\cline { 2 - 7 } Tes & $\mathbf{T}$ & TT & Tinggi & Rendah & Rata \\
\hline Siklus I & 15 & 11 & 85 & 50 & 65.6 & $\mathbf{5 7 . 6}$ \\
& & & & & & $\mathbf{9}$ \\
\hline Siklus II & $\mathbf{2 6}$ & $\mathbf{0}$ & $\mathbf{9 5}$ & $\mathbf{6 5}$ & $\mathbf{7 8 . 2}$ & $\mathbf{1 0 0}$ \\
& & & & & $\mathbf{7}$ &
\end{tabular}

Sumber: Analisis data hasil tes murid

Tabel $4.11 \mathrm{di}$ atas dapat dilihat bahwa nilai rata-rata hasil belajar Pendidikan Kewarganegaraan Murid kelas IV Sekolah Dasar Negeri 3 Jagong Kecamatan Pangkajene Kabupaten Pangkep yang dilaksanakan dalam dua siklus mengalami peningkatan pada akhir siklus I nilai rata-rata yang diperoleh murid adalah 65.6 dan berada pada kategori sedang, sedangkan pada akhir siklus II nilai rata-rata yang diperoleh murid adalah 78.27 dan berada pada kategori yang tinggi. Dari hasil ini menunjukkan adanya peningkatan nilai rata-rata hasil belajar murid kelas IV Sekolah Dasar Negeri 3 Jagong Kecamatan Pangkajene Kabupaten Pangkep melalui penerapan model pembelajaran Snowball Throwing dari $57.69 \%$ menjadi $100 \%$. Besarnya persentase peningkatan hasil belajar murid berdasarkan kriteria ketuntasan belajarnya adalah $42.31 \%$. Ini berarti murid yang mengalami peningkatan hasil belajar dari Siklus I ke Siklus II dan adalah 15 orang murid dari 26 murid. Secara umum pembelajaran Pendidikan Kewarganegaraan melalui penerapan model pembelajaran Snowball Throwing kelas IV Sekolah Dasar Negeri 3 Jagong Kecamatan Pangkajene Kabupaten Pangkep sudah bisa mengantar murid untuk lebih mudah memahami materi pelajaran yang diberikan.

\section{Refleksi}

Pembelajaran pada tindakan siklus dilaksanakan dengan menerapkan model pembelajaran Snowball Throwing untuk memperoleh data tindakan siklus II dilakukan pengamatan, tes. Hasil pengamatan, tes selama tindakan, dianalisis dan didiskusikan dengan pengamat sehingga diperoleh hal-hal (a) Presentasi materi berjalan sesuai yang direncanakan. Murid merasa senang mengerjakan soal-soal yang telah diberikan, (b) Murid tidak mengalami kesulitan memahami materi yang diberikan, (c) Hasil tes tindakan siklus II menunjukkan bahwa semua murid kelas IV Sekolah Dasar Negeri 3 Jagong Kecamatan Pangkajene Kabupaten Pangkep memperoleh nilai sesuai indikator yang ditetapkan yaitu 65 .

\section{KESIMPULAN}

Berdasarkan rumusan masalah, hasil analisis data dan pembahasan, maka hasil penelitian ini dapat disimpulkan bahwa penggunaan model pembelajaran Snowball Throwing dapat meningkatkan hasil belajar Pendidikan Kewarganegaraan pada Murid Kelas IV Sekolah Dasar Negeri 3 Jagong Kecamatan Pangkajene Kabupaten Pangkep. Berdasarkan hasil pengamatan pada siklus I, bahwa hasil belajar murid pada tindakan siklus I dari 26 murid Kelas IV Sekolah Dasar Negeri 3 Jagong Kecamatan Pangkajene Kabupaten Pangkep terdapat 3.85\% murid yang masuk dalam kategori sangat tinggi, 19.23\% masuk dalam kategori tinggi, 30.77\% masuk dalam kategori sedang, $19.23 \%$ masuk dalam kategori rendah dan $26.92 \%$ masuk dalam kategori sangat rendah dengan nilai rata-rata yaitu sebesar 65.6. Setelah dikategorisasikan diketahui bahwa tingkat hasil belajar murid kelas IV Sekolah Dasar Negeri 3 Jagong Kecamatan Pangkajene Kabupaten Pangkep berada ada kategori sedang. sedangkan ketuntasan hasil belajar murid hanya 9 orang murid berada dalam kategori tuntas dan 6 orang murid masuk dalam kategori tidak tuntas dan meningkat pada siklus II nilai rata-rata hasil belajar Pendidikan Kewarganegaraan 78,27 berada pada kategori tinggi sedangkan ketuntasan hasil belajar murid 
juga meningkat menjadi 15 orang murid masuk dalam kategori tuntas.

\section{DAFTAR PUSTAKA}

[1] Arikunto, dkk. (2011). Penelitian Tindakan Kelas. Bumi Aksara: Jakarta

[2] Asmani M, J. (2011). 7 Tips Aplikasi Pakem (Pembelajaran Aktif, Kreatif, Efektif, dan Menyenagkan). Jogjakarta: Diva Press

[3] Budiningsih, A. (2004). Belajar \& Pembelajaran. Jakarta: PT. Rineka Cipta

[4] Haling, A. (1994). Kurikulum dan Pembelajaran. Bumi Aksara: Bandung

[5] Haling, A. (2007). Belajar dan Pembelajaran. FIP UNM: Makassar

[6] Hamalik, O (2001). Proses Belajar Mengajar. Bumi Aksara: Bandung

[7] Hamalik, O. (1994). Proses Belajar Mengajar. Bumi Aksara: Bandung

[8] Kaelan \& Zubaidi, A. (2007). Pendidikan Kewarganegaraan untuk Perguruan Tinggi. Paradigma: Jogjakarta .

[9] Kisworo. (2008). Pembelajaran Kooperatif Tipe Snowball Throwing. UNESA. Bandung.

[10] Muslich, M. (2007). KTSP Pembelajaran Berbasis Kompetensi dan Kontekstual. Bumi Aksara. Jakarta.

[11] Poerwadarminto, W.JS. (1991). Kamus Bahasa Indonesia. Balai Pustaka: Jakarta.

[12] Raharjo \& Daryanto. (2012). Model Pembelajaran Inovatif. Jogjakarta: Gava Media.

[13] Rusman. (2010). Model-model Pembelajaran Mengembangkan Profisonalisme Guru. Bandung: PT RajaGrafindo Persada

[14] Slameto. (1995). Belajar dan Faktor-faktor yang Mempengaruhinya (edisi II). PT. Rineka Cipta: Jakarta

[15] Suryono \& Hariyanto. (2011). Belajar dan Pembelajaran. Bandung: PT Remaja Rosdakarya

[15] Suardi, S. (2018). Peningkatan Hasil Belajar Sosiologi Pokok Bahasan Interaksi Sosial Melalui Metode Diskusi pada Siswa Kelas X MA. Muhammadiyah Panaikang Kacamatan Bissappu Kabupten Bantaeng. " JURNAL ETIKA DEMOKRASI (JED)" PRODI PPKn FKIP UNISMUH MAKASSAR, 2(1).

[16] Syafri. 2009. Faktor-faktor yang mempengaruhi hasil belajar. PT. Rineka Cipta: Jakarta

[17] Syah, M. (2003). Psiokologi Belajar. Jakarta: PT Rajagrafindo Persada.

[18] Taniredja, dkk. (2011). Model-model pembelajaran Inovatif. Bandung: Alfabeta

[19] Undang-Undang Republik Indonesia No. 20 Tahun 2003 Tentang Sistem Pendidikan Nasional. CV Dewi: Jakarta

[20] Wiriatmojo. (2005). Psikologi Belajar. Jakarta: Rineka Cipta
[21] Yamin, M.(2012). Panduan Manajemen Mutu Kurikulum Pendidikan. Jogjakarta: Diva Press

[22] Yani. (2011). Meningkatkan Hasil Belajar PKn Melalui Penerapan Model Pembelajaran Cooperative Tipe Snowball Throwing pada Murid Kelas IV SD Inpres Barru I Kecamatan Barru Kabupaten Barru. Universitas Muhammadiyah Makassar. 